\title{
Study on the Application of Banana Stems and Leaves in Pleurotus Ostreatus Production
}

\author{
Jin-Song YANG ${ }^{1, \text { a }}$, Hai-Yang GUO ${ }^{1, b}$, Xue-Li JU ${ }^{1, c}$ and \\ Hai-Sheng TAN ${ }^{2, \mathrm{~d}^{*}}$
}

( ${ }^{1}$ College of food science and technology, Hainan University, Haikou, Hainan 570228, China

${ }^{2}$ Materials and Chemical Engineering, Hainan University, Haikou, Hainan 570228, China)

aemail: food868@163.com, bemail:249420070@qq.com, cemail: 1379240630@qq.com, ${ }^{\mathrm{d}}$ email: ths688@163.com

*Corresponding author: ths688@163.com

Keywords: Banana stems and leaves; Pleurotus ostreatus; mycelium; protein content

\begin{abstract}
In this experiment, banana stems and leaves were used as the main raw materials to culture Pleurotus ostreatus, and the effects of different ratio of banana stems and leaves, bran and Tenebrio molitor feces on mycelial growth and protein content of Pleurotus ostreatus were discussed. The results showed that the growth rate of hyphae in the mixed medium of banana stem and leaf juice was $4 \%-6 \%$ higher than that of other ratio in the experiment of banana stem and leaf juice as accelerator. $10 \%$ bran and $10 \%$ Tenebrio molitor feces mixed with banana stems and leaves in the cultivation of mushroom, mycelium growth speed and high protein content.
\end{abstract}

\section{Introduction}

Banana is a kind of monocotyledon herb of musa plantain family, which is widely cultivated in tropical and subtropical regions [1]. Banana industry is growing at an extremely fast speed. Behind its huge market share and total consumption, there is a serious problem of resource waste, that is, banana will produce about $75 \%$ of stem and leaf by-products during harvest [2].Most of the stem and leaf resources are discarded at will, and only a small part of banana stem and leaf are used as fertilizer, which not only affects the environment, but also wastes resources. Studies have found that banana leaves and stems contain high soluble carbohydrates and various vitamins, high crude protein content and rich mineral elements content in banana leaves [3-4].Banana stems and leaves can be used as feed materials, and can also be used as organic fertilizers with microorganisms, which can improve the physical and chemical properties of soil, increase the content of soil organic matter, N, P, K and other elements, and promote the growth of crops [5-7].Therefore, rational exploitation and utilization of banana stem and leaf resources can not only reduce environmental pollution and improve the utilization rate of resources, but also have good economic and social benefits.

Pleurotus ostreatus, belonging to the lateral ear family of the order hydatidiformes under the door of basidiomycetes, are aerophilic fungi. The mycelium artificially cultivated is white, white and dense on AGAR medium. Mushroom mycelium in $5{ }^{\circ} \mathrm{C} \sim 35{ }^{\circ} \mathrm{C}$ can grow, the optimum growth temperature of $24{ }^{\circ} \mathrm{C} \sim 28{ }^{\circ} \mathrm{C}$ [8]. In the process of cultivating pleurotus edodes, adding a certain amount of calcium, magnesium, sulfur, phosphorus and other mineral elements in the culture medium can promote the growth of mushroom mycelia [9].

Pleurotus ostreatus is a kind of traditional artificially cultivated edible fungus, which contains many vitamins, polysaccharides and minerals, etc, which can improve human metabolism and enhance physical fitness, and has certain effects on lowering blood cholesterol and inhibiting tumor cells [10]. Pleurotus ostreatus are favored by consumers because of their unique taste and rich nutrition. However, with the continuous increase in the prices of traditional cultivation materials such as cottonseed husks, bagasse, miscellaneous wood chips and crop stalks, the production cost of edible fungi increases gradually, and the economic benefits decrease gradually, which is not conducive to the stable development of edible fungi industry. It is an urgent problem for the market 
of edible fungi to explore new cultivation materials for cultivating edible fungi and to find more economical sources of cultivated materials.

In this study, with banana stem and leaf as main raw materials and bran and Tenebrio molitor feces as auxiliary materials, the mushroom was cultured, the growth rate and protein content of mushroom mycelium were observed, the test results were analyzed, the optimal ratio of banana stem and leaf compound medium was sought, and the benefit rate of agricultural and sideline products was improved.

\section{Materials and Methods}

\section{Materials}

Pleurotus ostreatus is Nongping No.19 species, which is tested by our laboratory. Banana stems and leaves were collected from the experimental base of Hainan University College of agriculture. Cut banana stems and leaves into about $2 \mathrm{~cm}$, sun exposure for 2 days; Tenebrio molitor feces: Tenebrio molitor feces are provided by Hainan spider king pharmaceutical company.

\section{Preparation of Culture Medium}

\section{Preparation of PDA Medium}

$200 \mathrm{~g}$ potatoes, add $1000 \mathrm{~mL}$ water to boil for $30 \mathrm{~min}$ after cutting, filter with filter cloth, pour the filtrate into the pot, and dissolve to $1000 \mathrm{~mL}$. Add $20 \mathrm{~g}$ glucose and $20 \mathrm{~g}$ agar-agar powder (liquid PDA medium without agar-agar powder), mix and then divide them into triangular bottles for sterilization.

\section{Preparation of Banana Stem and Leaf Juice Culture Medium}

Wash and shred the fresh banana stems and leaves, put them into a crusher and mash them. Then, the banana stem and leaf juice and PDA medium were prepared according to the ratio shown in table 1, sterilized and poured into the plate, and each treatment was repeated three times.

Table 1 Mixture ratio banana stem and leaf juice medium

\begin{tabular}{ccccc}
\hline number & $\begin{array}{c}\text { PDA culture } \\
\text { medium } / \mathrm{mL}\end{array}$ & Banana juice $/ \mathrm{mL}$ & total $/ \mathrm{mL}$ & $\begin{array}{c}\text { Percent } \\
\text { concentration } \\
/ \%\end{array}$ \\
\hline A & 100.0 & 0.0 & 100.0 & 0.0 \\
B & 98.0 & 2.0 & 100.0 & 2.0 \\
C & 96.0 & 4.0 & 100.0 & 4.0 \\
D & 94.0 & 6.0 & 100.0 & 6.0 \\
E & 92.0 & 8.0 & 100.0 & 8.0 \\
F & 90.0 & 10.0 & 100.0 & 10.0 \\
\hline
\end{tabular}

\section{Preparation of Banana Stalk and Leaf Culture Materials}

According to the proportion shown in table 2, the banana stem and leaf culture material was prepared, and the water content in the medium was $60 \%-65 \%$. The $200 \mathrm{~g}$ culture medium was put into $1000 \mathrm{~mL}(200 \mathrm{~g} / 1000 \mathrm{~mL})$ triangular bottle for sterilization reserve. Respectively connected to the mushroom mycelium cultured the $25{ }^{\circ} \mathrm{C}$ temperature 7 days. The growth rate of mycelium was recorded. The protein content was determined by taking $1 \mathrm{~g}$ culture substance from each test. Three repetitions were performed for each treatment. 
Table 2 The ratio of banana stem, leaf and Tenebrio molitor feces

\begin{tabular}{cccc}
\hline number & banana stems and leaves $/ \mathrm{g}$ & wheat bran $/ \mathrm{g}$ & tenebrio molitor feces $/ \mathrm{g}$ \\
\hline 1 & 95.0 & 5.0 & 0.0 \\
2 & 90.0 & 10.0 & 0.0 \\
3 & 85.0 & 15.0 & 0.0 \\
4 & 80.0 & 20.0 & 0.0 \\
5 & 75.0 & 25.0 & 0.0 \\
6 & 95.0 & 0.0 & 5.0 \\
7 & 90.0 & 0.0 & 10.0 \\
8 & 85.0 & 0.0 & 15.0 \\
9 & 80.0 & 0.0 & 20.0 \\
10 & 75.0 & 0.0 & 25.0 \\
11 & 80.0 & 5.0 & 15.0 \\
12 & 80.0 & 10.0 & 10.0 \\
13 & 80.0 & 15.0 & 5.0 \\
14 & 100.0 & 0.0 & 0.0 \\
\hline
\end{tabular}

\section{Determination of Protein}

According to literature [11], protein was determined by kjeldahl method.

\section{Results and Analysis}

\section{The Germination of Mycelia of Mushroom in the Mixed Culture Medium of Banana Stem} and Leaf Juice

Use PDA medium mushroom mycelium, the resurrection of the vaccination to different concentrations of banana stem leaf juice medium center, $25^{\circ} \mathrm{C}$ temperature intervals after training to sprout hypha day measuring the diameter of the hyphae.

Table 3 Growth of Pleurotus ostreatus on Banana Stem and Leaf Juice Medium

\begin{tabular}{|c|c|c|c|c|c|c|c|c|c|}
\hline \multirow{2}{*}{$\begin{array}{c}\text { num } \\
\text { ber }\end{array}$} & \multicolumn{9}{|c|}{ Diameter of mushroom mycelium at different dates $/ \mathrm{mm}$} \\
\hline & $1 d$ & $2 \mathrm{~d}$ & $3 d$ & $4 d$ & $5 \mathrm{~d}$ & $6 \mathrm{~d}$ & $7 \mathrm{~d}$ & $8 \mathrm{~d}$ & $9 \mathrm{~d}$ \\
\hline A & $0.7 \pm 0.10^{\mathrm{a}}$ & $1.0 \pm 0.12^{\mathrm{b}}$ & $2.4 \pm 0.12^{\mathrm{e}}$ & $8.0 \pm 0.15^{\mathrm{e}}$ & $16.8 \pm 0.14^{\mathrm{e}}$ & $27.5 \pm 0.28^{\mathrm{d}}$ & $42.4 \pm 0.24^{\mathrm{e}}$ & $56.9 \pm 0.22^{\mathrm{e}}$ & $68.8 \pm 0.13^{\mathrm{e}}$ \\
\hline $\mathrm{B}$ & $0.8 \pm 0.12^{\mathrm{a}}$ & $0.9 \pm 0.13^{\mathrm{b}}$ & $5.1 \pm 0.21^{\mathrm{c}}$ & $10.5 \pm 0.1^{\mathrm{c}}$ & $23.0 \pm 0.32^{\mathrm{c}}$ & $35.1 \pm 0.16^{\mathrm{c}}$ & $50.1 \pm 0.16^{\mathrm{c}}$ & $65.6 \pm 0.15^{\mathrm{c}}$ & $79.4 \pm 0.24^{\mathrm{c}}$ \\
\hline $\mathrm{C}$ & $0.7 \pm 0.12^{\mathrm{a}}$ & $1.0 \pm 0.11^{\mathrm{b}}$ & $7.2 \pm 0.14^{\mathrm{b}}$ & $13.3 \pm 0.3^{\mathrm{b}}$ & $27.2 \pm 0.15^{\mathrm{b}}$ & $41.2 \pm 0.25^{\mathrm{b}}$ & $53.5 \pm 0.25^{\mathrm{b}}$ & $69.5 \pm 0.16^{\mathrm{b}}$ & $81.0 \pm 0.22^{b}$ \\
\hline $\mathrm{D}$ & $0.7 \pm 0.13^{\mathrm{a}}$ & $1.3 \pm 0.12^{\mathrm{a}}$ & $9.3 \pm 0.22^{\mathrm{a}}$ & $17.6 \pm 0.2^{\mathrm{a}}$ & $32.9 \pm 0.32^{\mathrm{a}}$ & $44.2 \pm 0.14^{\mathrm{a}}$ & $58.4 \pm 0.17^{\mathrm{a}}$ & $73.4 \pm 0.13^{\mathrm{a}}$ & $86.8 \pm 0.25^{\mathrm{a}}$ \\
\hline $\mathrm{E}$ & $0.8 \pm 0.08^{\mathrm{a}}$ & $1.0 \pm 0.14^{b}$ & $2.6 \pm 0.31^{\mathrm{e}}$ & $8.3 \pm 0.15^{\mathrm{e}}$ & $17.0 \pm 0.16^{\mathrm{e}}$ & $29.5 \pm 0.17^{\mathrm{d}}$ & $43.7 \pm 0.31^{\mathrm{e}}$ & $57.5 \pm 0.24^{\mathrm{e}}$ & $70.0 \pm 0.16^{\mathrm{e}}$ \\
\hline $\mathrm{F}$ & $0.8 \pm 0.06^{\mathrm{a}}$ & $1.0 \pm 0.13^{\mathrm{b}}$ & $3.4 \pm 0.23^{\mathrm{d}}$ & $9.1 \pm 0.24^{\mathrm{d}}$ & $18.9 \pm 0.12^{\mathrm{d}}$ & $34.1 \pm 0.15^{\mathrm{c}}$ & $47.1 \pm 0.34^{\mathrm{d}}$ & $59.4 \pm 0.17^{\mathrm{d}}$ & $72.5 \pm 0.28^{\mathrm{d}}$ \\
\hline
\end{tabular}

Note: there was no significant difference $(p>0.05)$ between the data with the same letter marked by the same average in the same column, and there was a significant difference between the data marked with different letters $(p<0.05)$.

It is known from table 3 that mushroom mycelia did not germinate within two days of initial access, and all the mycelia began to grow on the third day, but $\mathrm{C}$ and compared with other plates, the mycelium of plate $\mathrm{D}$ germinated faster, and the growth rate was basically stable at day 5 . The mycelium growth rate of plate $\mathrm{C}$ and $\mathrm{D}$ was faster than that of other plates. By day 9 , tablets $\mathrm{C}$ and $\mathrm{D}$ were nearly full of tablets. Therefore, it contains $4 \%$ to $6 \%$ banana stem and leaf juice, which enables rapid germination of mushroom mycelia.

Effect of Bran and Tenebrio Molitor Feces Addition on the Growth of Mushroom in the Cultivation Material of Banana Stem and Leaf

The growth of mushroom fungus was better than that of control group in the cultivation material of banana stem and leaf with bran. In the banana stalk and leaf culture materials with bran and Tenebrio molitor feces added at the same time, the growth was not only better, but the protein 
content was significantly increased ( $\mathrm{p}<0.05)$, as shown in table 4.Bran has good water absorption, can improve the problem of poor air permeability of banana stem and leaf, and can provide better protein and vitamin source for mushroom growth. In contrast, although Tenebrio molitor feces contains a lot of organic matter and minerals, the microfilm formed by insect digestive tract secretion on the surface of Tenebrio molitor feces has the function of preserving water rather than absorbing water to improve air permeability. It cannot be used as improved banana stem and leaf culture medium alone. The mycelium of a group of Pleurotus ostreatus, which ACTS as an additive after bran and Tenebrio molitor feces are mixed, is similar to that of a group of Pleurotus ostreatus which only adds bran. Therefore, the mixing of bran and Tenebrio molitor feces can not only improve the air permeability of banana stalk and leaf culture materials, but also provide a good source of vitamin and protein for the growth of mushroom.

Table 4 Effect of different wheat bran and Tenebrio molitor feces on the growth of Pleurotus ostreatus

\begin{tabular}{|c|c|c|c|c|c|c|c|c|}
\hline number & $\begin{array}{l}\text { mycelium } \\
\text { growth rate }\end{array}$ & $\begin{array}{c}\text { mycelial } \\
\text { protein } \\
\text { content(dry } \\
\text { basis } \%) \\
\end{array}$ & number & $\begin{array}{l}\text { mycelium } \\
\text { growth rate }\end{array}$ & $\begin{array}{c}\text { mycelial } \\
\text { protein } \\
\text { content(dry } \\
\text { basis \%) } \\
\end{array}$ & number & $\begin{array}{l}\text { mycelium } \\
\text { growth rate }\end{array}$ & $\begin{array}{c}\text { mycelial } \\
\text { protein } \\
\text { content(dry } \\
\text { basis } \%) \\
\end{array}$ \\
\hline 1 & ++ & $13.58 \pm 0.10^{\mathrm{d}}$ & 6 & & \multirow{5}{*}{$\begin{array}{c}\text { no } \\
\text { measurement } \\
\text { data }\end{array}$} & 11 & ++ & $25.26 \pm 0.11$ \\
\hline 2 & ++ & $12.92 \pm 0.11^{\mathrm{d}}$ & 7 & $\begin{array}{l}- \\
-\end{array}$ & & 12 & +++ & $38.54 \pm 0.12$ \\
\hline 3 & +++ & $16.23 \pm 0.13^{c}$ & 8 & - & & 13 & +++ & $\underset{\mathrm{a}}{36.97 \pm 0.12}$ \\
\hline 4 & +++ & $15.95 \pm 0.12^{\mathrm{c}}$ & 9 & - & & 14 & + & $6.25 \pm 0.13^{\mathrm{e}}$ \\
\hline 5 & ++++ & $16.33 \pm 0.08^{\mathrm{c}}$ & 10 & & & & & \\
\hline
\end{tabular}

Note: + represents the growth rate of mycelium, and the more + , the faster the growth rate of mycelium. - The mycelium does not grow. There was no significant difference $(p>0.05)$ between data with the same letter marked by the same average of the same column, and there was a significant difference between data marked with different letters $(\mathrm{p}<0.05)$.

\section{Conclusion}

The mycelium of Pleurotus ostreatus can be cultivated with banana stem leaves, wheat bran and Tenebrio molitor feces. Adding bran in the stem and leaf of banana can improve the poor permeability of the banana stem and leaf. Adding Tenebrio molitor feces can provide protein and improve the growth speed and protein content of the mycelium of the mushroom. In accordance with the proportion of $10 \%$ bran and $10 \%$ Tenebrio molitor feces, the growth speed of the mushroom is fast, and the protein content is $38.54 \%$. The banana stem leaf juice containing $4 \%-6 \%$ can better promote the growth of Pleurotus ostreatus. Therefore, breaking through the limitations of the original cultivation materials, using banana stem and leaf and other new cultivation materials to cultivate Pleurotus ostreatus can obtain enormous economic benefits.

\section{Acknowledgement}

This research was financially supported by the National Natural Science Foundation of China (No. 31460621).

\section{References}

[1] Song Zhiping, CAI Junpeng. Exploitation and utilization of banana stem and leaf resources. Resource development and market, 2005, 21(1): 59-60

[2] Zhang Xuejuan, Wang Chong, Li Baoshen. Current situation and prospect of utilization of banana stem and leaf residues in China. Tropical agricultural science, 2015, 35(10): 70-74 
[3] Xu shaocheng, Yang Jinsong, Yang Rui. Isolation and identification of lactic acid bacteria in banana stems and leaves. Guangdong agricultural science, 2010 (4): 122-124,127

[4] Qin baoshan, Qin yongrong. Current situation and prospect of research on edible fungi cultivated with new media. China agricultural science bulletin, 2010, 26(16): 233-228

[5] Wang Qian, Zhou Hanlin, Tan Haisheng, Yang Jinsong. Effects of different additives on the quality of banana stalk and leaf silage. Guangdong agricultural science, 2013 (1): 12-15

[6] Wang Zenghuang, Wang Wenze, Yang Lin. Research progress of banana stem and leaf as feed material. China journal of animal husbandry, 2016, 52(17): 82-85

[7] Yang YongZhi, Wang Shuming, Yang Qin. Development and utilization of banana stem and leaf resources. Modern agricultural technology, 2012(4): 294-295

[8] Robert Inklaar, Marcel Timmer. Of Yeast and Mushrooms: Patterns of Industry-Level the Productivity Growth. Journal of German Economic Review, 2007, 8 (2): 10-13

[9] Chen Lixin, Huang Zhuozhong, Chen Zhenni. Nutrient composition and heavy metal analysis of mushroom cultivation with eucalyptus bark and eucalyptus cuttings. Journal of southern agriculture, 2015, 46(10): 1883-1886.

[10] Xu Chuanchun. Economic benefits of mushroom production. Anhui agricultural science bulletin, 2012, 18(24): 74,116.

[11] Zhang Shuihua. Food analysis. China light industry press. 2010(1): 156-159 